\title{
Chemical-genetic classification of microcrystalline oxides from kimberlite groundmass and new system of diamondiferrouse prospecting
}

\author{
Bovkun A.V., Garanin V.K., Kudriavtseva G.P., Possukhova T.V.
}

Moscow State University, Geological dep.

Kimberlites are main rocks, containing to industrial concentration of diamonds, therefore the valuation of their diamondiferrouse prospecting has a scientific and practical interest. At Diamond Deposits Laboratory a technique of valuation of diamond contain in kimberlite pipes, based on study of chemical composition of microcrystalline (less than $100 \mathrm{~A}$ ) oxides from kimberlite groundmass is developed.

\section{Objects and methods}

The data base, including 396 full microprobe analyses of spinels, ilmenites and rutiles from Zolotitskoye, Verkhotinskoye and Kepinskoye kimberlite fields and Tourinskoye basaltic groups was created (Garanin,Posukhova, 1994).

For reception of the correct analytical information a special technique, enabling was developed to grew to learn close on a structure of a multicomponent ironferrouse oxides, the size of which is close to resolution of a device. The basis of a technique is made by 2 programs: the program of the quantitative analysis of the images on degrees of brigtness and program of the quantitative modal analysis, developed by the authors earlier (Garanin et al., 1984).

The technique includes filming of the images of a kimberlite groundmass with inclusions of microcrystalline oxides in back-scattering electrons with material contrast and in characteristic $\mathrm{x}$-ray beams; imposing of the received images with refinement of phase borders; quantitative microprobe analysis of phases; identification of phases on the basis of created in laboratory of a database and association in groups on a technique of the claster analysis. The quantitative analysis received color images permits to establish the friquency of allocated chemical-genetic groups of oxides in kimberlites and on the basis of established correlation connections to evaluate the diamondiferrouse prosperities.

\section{Results and Discussion}

The physical-chemical, thermodynamic and kinetic conditions of kimberlite crystallization were estimated at the base of microcrystalline phases chemical composition peculiarities. By cluster analyses methods 12 chemical-genetic groups of microspinels, 5 chemical-genetic groups of microilmenites were distinguished.The oxides from distinguished groups differ by contents of main components and by distribution in different kimberlite pipes (Garanin V.K. \& Posukhova T.V., 1994).

The high- and medium-Cr-picrochromites of the first and second cluster groups were crystallized in deep conditions in diamond-stable thermodynamic region (Foley,1985). The picroferro- and picroferrichromites belonged to the third 
through the fifth cluster groups and the $\mathrm{Mg}-\mathrm{Cr}$-Al-titanomagnetites belonging to the eighth through the tenth cluster groups were crystallized in less depth in diamond - non - stable thermodynamic region (fig.2). The high - and medium Cr-picrochromites of the first and the second cluster groups are attributed to the beginning of the crystallization processes. They occur in inner parts of inclusions in microcrystalline olivine. The Fe-Ti-rich phases belonging to the eighth through the tenth cluster groups characterize the ending of crystallization processes. They occur in outer parts of microcrystalline grains in kimberlite groundmass.

The long and complicate kimberlite magma evolution was accompanied by modification of P-T and redox conditions. The later may be traced by the crystallization trends, which are specific for each kimberlite field and pipe.

The rich pipes of Zolotitskoye field are characterized by sharing trend: from the high- and medium- Cr-picrochromites of the first and the second cluster group to $\mathrm{Cr}$-ulvospinels belonged to the sixth through the seventh cluster groups. The first prevails. The high-Ti-ferrous phases, such as ilmenites and rutiles are absent in Zolotitskoye field. It is very important, that the high - $\mathrm{Cr}$ - picrochromites of the first cluster group were established only in Zolotitskoye field pipes and in Verkhotinskoye and Kepinskoye fields they are absent.

The poor pipes of Verkhotinskoye field are characterized by sharing trend. There are only two kinds of oxides: the medium-Cr-picrochromite of the second cluster group and the $\mathrm{Mg}$-Cr-Al-titanomagnetite of the eighth cluster group. The last kind of oxides prevails. Another phases are absent. It means, that the kimberlites of Verkhotinskoye field pipes formed at lesser depths and under the conditions of higher oxygen fugacity (Irvine, 1967) than the kimberlites of Zolotitskoye field pipes.

The poor pipes of Kepinskoye field are characterized by full trend: from mediumCr-picroferrochromites of the third cluster group to magnetites of the tenth cluster groups, different ilmenites (fig.3) and rutiles. The occurrence of medium-Crpicroferro-chromites of the third cluster group means, that these kimberlites were formed at the smaller depths in diamond - non - stable thermodynamic region.

Picroilmenite exists as inclusions in olivine and also as xenomorphic grains, which differ from the inclusions. Mn-ilmenite forms rims on spinel grains. Titanomagnetite forms rims on picroilmenite grains and small grains in kimberlitic groundmass. The microilmenite crystallization trend from gemopicroilmenites of the second cluster group to Fe-pirofanites of the fifth cluster group was established. Such trend testifies slow cooling at low temperatures (Garanin et al.,1985). The concentration of $\mathrm{Mg}$ and the indicator index $\mathrm{Fe} 3+/ \mathrm{Fe} 3++\mathrm{Fe} 2+$ decrease and the concentration of $\mathrm{Mn}$ increases during the transition from 2 cluster group to 3 and 4 groups that points on the progressive increasing of potashing and oxiding during the ilmenite crystallization in Kepinskoye field kimberlite. The occurrence of titanomagnetites, ilmenites and rutiles means, that these kimberlites have been forming during the long time, under the conditions of fast and high of $\mathrm{Fe} 3+$ and oxygen activities increasing. According to mutual interrelation of the minerals the following probable scheme of events can be proposed: on the first stage of kimberlitic melt crystallization $\mathrm{Cr}$ picrochromite cores, which correspond to the most favourable conditions of 
diamond preservation crystallize. Such kind of spinels are similar to those from kimberlite groundmass of the most high-diamondiferous pipes: Mir, Internatsionalnaya. Further, as the crystallization proceeds olivine crystals with inclusions of picroferro- and picroferrichromites start to appear, and the centers of early microspinels formed medium-chromium, iron rims down to titanomagnetite appearance. This stage is quite similar to the most typical diamondiferous kimberlites from the majority of productive pipes, but the composition of these spinels doesn't reach that of the high-diamondiferous bodies, that's why the primary diamond potential was lower, than that of known highdiamondiferous bodies from the Yakutian province. At the end of this stage intensive accumulation of titanium with forming of gemopicroilmenite and $\mathrm{Mn}$ ilmenite is established in the system. Abundance of titanium in the all allignment causes abrupt increasing of diamond dissolving, which could bring to dissolving of small diamond crystals and intensive destruction of high-defective crystals.

\section{Conclusion}

The difference of kimberlite magma evolution has the result in diamondiferrous of kimberlite pipes and it must be take into account during prospecting and exploration works. The results of our investigation show, that the connection between chemical composition of the microcristalline oxides from kimberlite groundmass and quantity and quality of diamond crystals exists.

The conditions of high contents of diamond are following: - the presence of high-Cr-picrocromites of the first cluster group with $>53.0$ wt.\% $\mathrm{Cr} 2 \mathrm{O} 3,<3.5$ wt.\% $\mathrm{TiO} 2$ and 9.0-14.0 wt.\% $\mathrm{MgO}$;

- absence and low content ( $<25 \%$ in accidental statistical reliable grains selection) of the titanomagnetites and other Ti-mineral-phases (ilmenites, rutiles, perovskite, sphen).

\section{References}

Garanin V.K., Kudriavtzeva G.P. \& Soshkina L.T., 1985. Ilmenite from kimberlites. Moscow, Izdat. Mosk. Univ., 240p.

Garanin V.K. \& Posukhova T.V., 1994. Typomorfism and crystallization scheme of microcrystalline oxides from kimberlite groundmass in Arkhangelsk diamondiferrous province. Izvestiya VUZov, ser. Geologiya \& Razvedka, N6, 8296.

Irvin T.N., 1967. Chromium spinel as a petrogenetic indicator. Canad.j. of Earth Sci, 71-75.

Folly P.S., 1985. The oxidation steigt of lamroitic Magmas. Miner. Petrographishe Mitteilungen, N34, 217-238. 